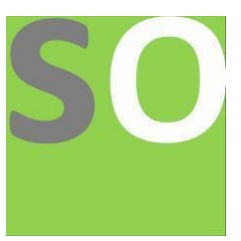

Article title: Historical overview of the System of National Accounts

Authors: Sajeevani Weerasekara[1]

Affiliations: Central Bank of Sri Lanka[1]

Orcid ids: 0000-0002-3366-6525[1]

Contact e-mail: sajeevanidod@y7mail.com

License information: This work has been published open access under Creative Commons Attribution License http://creativecommons.org/licenses/by/4.0/, which permits unrestricted use, distribution, and reproduction in any medium, provided the original work is properly cited. Conditions, terms of use and publishing policy can be found at https://www.scienceopen.com/.

Preprint statement: This article is a preprint and has not been peer-reviewed, under consideration and submitted to ScienceOpen Preprints for open peer review.

DOI: 10.14293/S2199-1006.1.SOR-.PP23YPU.v1

Preprint first posted online: 23 June 2021

Keywords: Systems of National Accounts, History, Economy 


\section{Historical overview of the System of National Accounts}

The main objective of this article is to present a brief overview of national accounts. Section 1.1 illustrates the historical overview of the system of national accounts (SNA). Section 1.2 presents the development of the SNA. Section 1.3 focusses on the Framework of SNA, classifications and measurements of economic activities and finally, section 1.4 presents brief overview of the government expenditure within the SNA framework.

\subsection{Historical overview of the national accounts}

\section{Estimates of national income to production of SNA}

"If the saying is true, that economics is eventually capable of benefiting the human race as much as the other sciences put together, it must be equipped not only with the scientific spirit, but also with the financial resources, of the older sciences". (Clark, 1965)

The history of national accounts extends as far back as the seventeenth century. As Stone and Meade (1977) states "to trace the origins of national economic accounting, we must go back to seventeenth century England, an age of great intellectual vigour, scientific curiosity and inventiveness". Further, according to the Kenadrick (1996) the first estimates of national income were made in the late seventeenth century by Sir William Petty and Gregory King in England and subsequently, Marshall Vauban in France (see Box 1). After those first attempts, until the late $19^{\text {th }}$ century there were many conventional presentations on various estimates for a variety of purposes such as estimating tax revenue and assessing income distribution. James Meade and Richard Stone in Britain, and Simon Kuznets in the United States, were some of the pioneers of that period and the accounting framework that they built created a solid foundation for subsequent development (Tily, 2009).

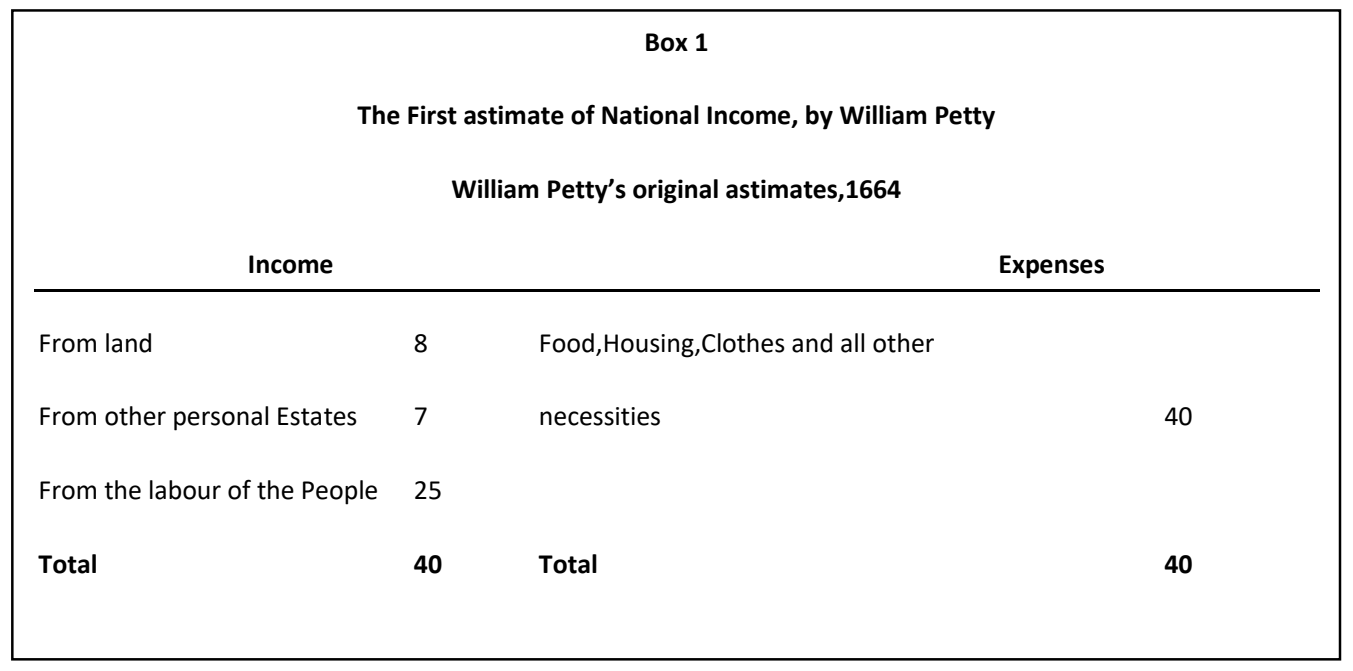


Copied from A History Of National Accounts, Andre Venoli (2005), which is copied from Richard Stone (Nobel Memorial Lecture,1984,p.7) England, in millions of pounds.

Further, taking of Census of Production in 1907 and the publishing a book entitled "An Elementary Manual of Statistics" in 1910 by Arthur L Bowley (1869-1957) were considerable events that brought the importance of national accounting to wider spectators. The first publication of the United States' national income estimate which was made by Simon Kuznets in 1934, and the establishment of the Central Economic Intelligence Service (CEIS), which was responsible for the compilation of national income estimates in the United Kingdom in 1939, marked the beginning of many events that helped to improve the system of national accounts (Kenadrick, 1996). As founding members of the CEIS, Professor Bowley, James Meade, Richard Stone and Colin Clark continued to improve national accounts estimates using the double entry bookkeeping method. At the recommendation of Keynes, who was the period's pioneering economist, a white paper based on national accounts estimates was appended to the United Kingdom budget in 1941, and heralded the improvement of national accounts systems.

As to Vanoli (2005) states "World War II marks a new turning point. It witnesses the real birth of national accounting and the extension of its use. Kaynes gives the impulse, worried about How to pay for war (1940)?" which greatly facilitated the improvement of national accounts. Similarly, the history of national accounts was immensely benefited by the involvement of Colin Clark. With his involvement, the system of national accounts was improved methodically and significantly. He made his full contribution to publishing quarterly estimates from production, income and expenditure perspectives, in both nominal and real terms, and further started to estimate distribution of income across the population and between industries.

The next phase in the field's advancement was based on the considerations of the national accounts system which comparable to the world. In 1945 the League of Nations summoned a group to develop guidelines on national accounts. Subsequently, a memorandum prepared by Richard Stone based on his work in the United Kingdom, Measurement of National Income and the Construction of Social Accounts ,Geneva, 1947 which is published as an appendix to a report on national income statistics, was a significant historical event in the SNA. It served as the basis for the first SNA formulated in 1952 and published in 1953 (United Nations, 1968). According to Kenadrick (1996) that publication served as a guideline to other nations beginning economic accounts and it provided a uniform basis for countries to report national income for publication. Unquestionably, this was a pivotal milestone in the history of modern SNA. 
This section presents the improvements to SNA throughout the history. Though the historical events regarding the development of a system of national accounts happened in the sequence described in the above sections, which took place year-by-year are also important to understanding the system well. This is because the SNA which was introduced in 1953 was considerably different to the 1993 SNA. As discussed in the previous section, Stone's 1947 sub-committee report was considered the stepping stone to the SNA. That report recommended a set of nine tables to present national income statistics. The set of accounts in Stone's appendix consisted of five sectors: productive enterprises, financial intermediaries, insurance and social security agencies, final consumers and the rest of the world. However, one of the most discussed weaknesses of this system is that it did not consider the effect of the recent World War II in its accounts, and also the fact that the accounts were based on a model of an advanced industrial economy in which monetary transactions dominated (International Monetary Fund, 1993).

The second phase of the development was the introduction of SNA 1953. With that, the importance of the systematic framework for national accounts came to the attention of many pioneering economists and policy makers. As Carson (1996) states SNA 1953 provided a methodical framework for recording and presenting the main flows involved in production, consumption, accumulation and external economic relations. Further transactions of those accounts were categorizing under three basic sectors which are enterprises, households and private non-profit institutions, and general government. Moreover, these accounts explicitly took the needs of developing countries into consideration also important milestone.

Following the criticism that emerged from the economists of that era, number of improvements took place to SNA 1953. For Instance, the construction of a framework for economic accounts related to national income and product, which are input and output reports, financial flow of funds, balance sheets and wealth statements and constant price estimates. The UN was the main driver of these improvements. However according to Kenadrick (1996), the UN statistical office did not recommend an integrated accounting system for national accounts as many countries lacked such accounts or were in the early stages of developing them. A few years later in 1957, an integration of various accounts was recommended by the United States National Accounts Review Committee which was chaired by the well-known economist Raymond Goldsmith. Even though the necessity of an integrated system was discussed in 1957, work on it did not begin until initiation of the UN Secretary 
General and the leadership of Richard Stone in 1963. The result of the years of action was the revised SNA, which is SNA 1968. Vanoli (2005) states that "support is come from....Stone himself, with whom French National accountant had crossed sword in the past. Following a UN request, he presented the report at the end of 1964, proposing drastic changes to the first SNA".

The following quote gives a more precise idea on the improvements incorporated in SNA 1968.

“....the new system incorporates additional classifications in respect of the activities of government and private non-profit bodies and transfers of income so as to furnish much more adequate tabulations of data than the old SNA concerning the effects of these bodies on the economy, the provision of social and community services, and the redistribution of incomes". (Preface to the UN report on A System of National Accounts, 1968).

SNA 1968 comprised with the many economic and accounting knowledge which can be identified as great achievements of the SNA history. Some of the improvements are differentiates industries from producers of government services, matrix presentation of accounts, input output analysis, sectorial wise accounts and financial tables.

The next chapter of the development of the SNA began with the limitations of the SNA 1968 and need to harmonize with international guidelines such as the IMF's Balance of Payment Manual. Discussion regarding the revision was begun by a group of international organizations including the UN in 1986, coming into effect in 1993. Known as SNA 1993, this document is considered the most important in national accounts today. This SNA provides an ample and detailed record of the complex economic activities taking place within an economy and between different economic agents that occur in markets or elsewhere. According to the overview of the International Monetary Fund (1993), "the system is built around a sequence of flow accounts linked to different types of economic activity taking place within a given period of time, together with balance sheets that record the values of the stocks of assets and liabilities held by the institutional units or sectors at the beginning and the end of the period."

SNA 2008 is the most recent advancement of SNA, however, with the exception of Australia, every other country still uses the 1993 SNA. The 2008 SNA consists of major and useful changes to the previous system such as the introduction of research and development as an asset, changes to the weapon system, and an increased coverage of financial and insurance services (OECD, 2013).

Jorgenson and Landefeld (2006) states that "SNA 1993 is a highly articulated integrated account structure that is the international guideline for national accounts around the world". With the idea of common systems of accounts throughout the whole world, it raises the possible question 
regarding why so many different SNA exist around the world. For instance, there are the International Monetary Fund (IMF) SNA and the Organization of Economic Corporation and Development (OECD) SNA. The answer to that question, however, is that the 1993 SNA was a joint publication of the UN, OECD and IMF. Further it is consistent with other data systems, such as the OECD's guidelines on Foreign Direct Investment, the IMF's manuals on the Balance of Payment and Government Finance Statistics (International Monetary Fund, 1993). Therefore, the SNAs of the aforementioned organizations are mostly one and the same.

In view of the above developments this study focuses on the SNA 1993 unless otherwise mentioned, and uses identification codes of SNA1993 for the easy reference. Because even a few years after the introduction of the SNA 2008, most countries still use SNA 1993 as their guideline to national accounts. For instance, OECD (2012), states that data for all countries are based on the SNA 1993, with the exception of Australia which has already adopted the SNA 2008.

\subsection{Framework of SNA}

In line with the developments took place in the field of national accounts there are many changes in terms of overall structure of national accounts, and in terms of the particular details within the accounts including definitions and measurement of economic activities. This section focuses on discussing the measurement and definitions involved in an SNA.

According to the International Monetary Fund (1993), "the SNA is a multi-purpose system, designed for economic analysis, decision taking and policy-making, whatever the industrial structure or stage of economic development reached by a country. The basic concepts and definitions of the System depend upon economic reasoning and principles which should be universally valid and invariant to the particular economic circumstances in which they are applied. Similarly, the classifications and accounting rules are meant to be universally applicable". As it describes, measuring the wealth of a nation is important in various ways, and measuring it in a universally accepted way is also very important. Therefore, this chapter will now describe the various classifications, measurement of economic activities and definitions use by the SNA. Jackson (2000), states that the main purpose of an SNA is to provide a complete record of the working of an economy. It is therefore worthwhile to describe the process that SNAs use for measuring economic activities.

"Economic activity" is the various transactions that occur within an economy. According to Kendrick(cited in Stone and Meade, 1977) economic activity can be referred to, at a simplistic level, as production, consumption and adding to wealth. Ohlsson (1961), separates economic activity from 
production, income distribution, investment and consumption. However, modern economic literature considers "economic activity" as very broad area and difficult to define. In SNA 1993, the economy is described as "a general equilibrium system in which interdependent economic activities involving countless transactions between different institutional units are carried out simultaneously".

Most of the literature in the field uses the common method to record economic activities as flows and stocks. As SNA 1993 describes the purpose of national accounts is to record stocks and flows, it is clear that flows and stocks are the basic and the broadest measurement of economic activity. On the word of Carson (1996)"Information relating to economic actions and the effects of events take place within a given period of time recorded as a flow and information relating to a position in, or holding of , assets and liabilities at point of time recorded as a stock". Though the measuring of economic activity is started from these basic concepts, by way of grouping, classifying and categorizing stocks and flows provides an more accurate and comprehensive measurement of the economic activities within the economy.

\subsubsection{Classification of institutional sectors}

This is one of the common classifications that SNAs use. In the very early stages of SNAs this classification was limited to two broad sectors: households and institutions. However, today this classification has broadened to cover five mutually exclusive sectors. According to SNA 1993, this classification is based on their principle functions, behaviour and objectives. Basically, the SNA 1993 classifies this into five sectors, and the following list illustrates the complete picture of national accounts.

Table 1.1-Sectors of the Economy 


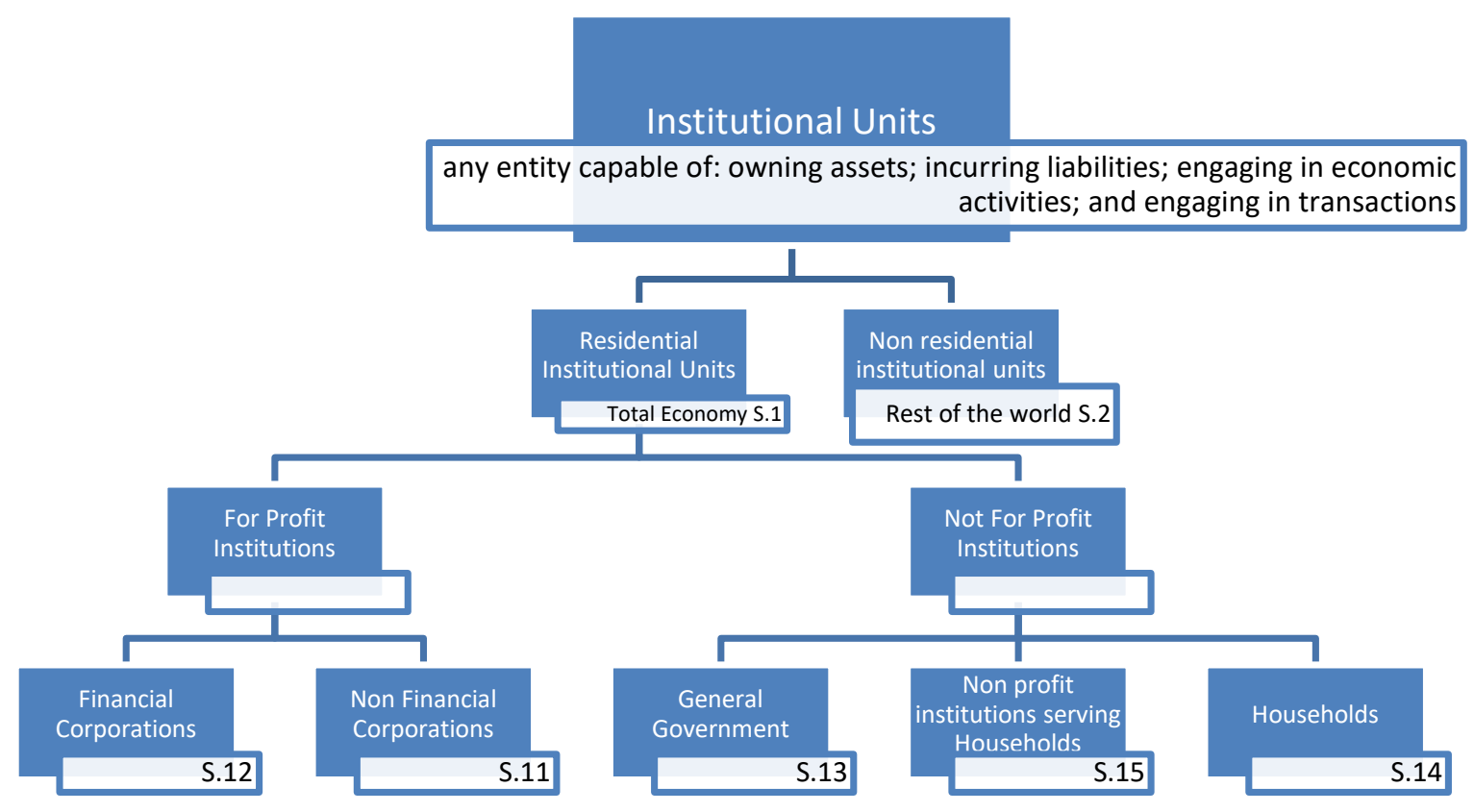

Identification code( s) refers to SNA93 classification code for sectors,

Source; New National Accounts, Dudley Jackson (2000) P 9 and SNA 1993

i. Financial corporations are institutions that are mainly involved in financial intermediation or in secondary financial activities.

ii. Non-financial corporations are institutions which are primarily involved in the production of market goods and non-financial services.

iii. General government is an institutional unit which produces principally non-market services for individual or collective consumption, and redistributes income and wealth in addition to accomplishing their political responsibilities and their role of economic regulation.

iv. Households are residents in the economy primarily living in houses, but also include people living long term in institutions including retirement homes, hospitals and prisons (Jackson, 2000). Further, SNA 1993 elaborates on this, articulating that the principal functions of households are the supply of labour, final consumption and, as entrepreneurs, the production of market goods and non-financial services.

v. Non-profit institutions serving households are legal entities which are primarily engaged in the production of non-market services for households. 


\subsubsection{Sequence of Accounts}

The sequence of accounts is another important feature of the SNA. This paragraph describes the sequence in relation to the SNA 1993. As Jorgenson and Landefeld (2006) states this describes transmission of income to wealth. He further states that major institutional sectors are the building blocks of the sequence of accounts. The economic process of production of income, consumption, investment and creation of wealth is reflected by the structure and the order of the sequence of accounts.

i. The current account records transactions related to production, distribution and use of income.

ii. The production account records the value of output within the system. Intermediate consumption should be deducted to arrive the balancing entry. Balancing item of this account is value added which summing up for measure Gross Domestic Product (GDP) of the economy.

iii. Distribution and use of income accounts is the next item in the sequence of accounts. This account consist of a set of a articulated accounts presenting how incomes are generated by production and distributed and redistributed among institutional units. For instance, salaries/compensation of employees and import taxes to the government are part of this accounts.

iv. The accumulation account records the acquisition and disposal of financial and nonfinancial assets, and also liabilities. This can be divided into capital accumulation and financial accumulation accounts.

v. The balance sheet records the opening and closing balance of the stocks of assets and liabilities held by all the institutional sectors of the economy.

Appendix will summarize the accounts, variables and balancing entries.

\subsubsection{Aggregates of the System}

Aggregates symbolize the current situation and future direction of the economy. Gross Domestic Production (GDP) is considered the key aggregate of the economy. SNA 1993 describes that as a key aggregate it measures production, and it is widely used by analysts, politicians, the press, business community and the public at large as an indicator of the economy. According to Carson (1996) it can be derived according to three approaches - the demand approach, which is the sum of the 
expenditure by final users, the production approach, which is some of the value added and the income approach, which is the sum of the primary income of residents.

While GDP is the key aggregate of national accounts, SNA provides number of other aggregates purpose of comparing the countries overtime. Gross National Income (GNI), Gross National Disposable Income (GNDI), national savings and national expenditure are some of those. GNI is the income receivable by residents of a country by participating in production or owning assets needed for production. National savings relates to disposable income not used for final consumption. National Expenditure (NE) is final consumption plus gross capital formation by resident units (Carson, 1996).

Accordingly, this article mainly discusses about the government expenditure which is part of NE discussed above. From this point onwards this article focuses on the classifications of the government expenditure and it's measurements as a part of national accounts.

\subsection{Government and its expenditure}

As described by International Monetary Fund (1993), the principal functions of government are to shoulder responsibility for the provision of goods and services extended to community or to individual households, and to finance their necessities out of taxation or other incomes, to redistribute income and wealth by means of transfers, and further to engage in non-market production.

Governments can engage in raising funds by collecting taxes from other institutional units and receive funds as transfers from other institutional units. Similarly, governments distribute their revenue to different categories such as free provisions to the community, for example public administration, defence, public health and law enforcement. Governments also engage in providing goods and services free, or at a very low price, to households, and they also execute transfers to other institutional units, especially to households, in order to redistribute income or wealth.

According to the modern classifications of SNA general government sectors comprise central, state and local governments, all social security funds at each level of government, and non-market not-forprofit institutions that are controlled by the government.

Central government has political authority over a whole country and it has authority to impose taxes on residents or non-residents who engage in economic activities of the country. It can comprise departments or ministries which may be responsible for a considerable amount of budget.

State government is another way of structuring the government. It exercises some of the functions in which central governments engage, but at a level below the central government and higher than other local government level institutions. Normally this kind of structure can be evidenced 
in larger countries which have federal constitutions. They have fiscal authority to impose taxes within the state area.

Local governments are sub-sectors of the central government, functioning as separate institutional units. Non-profit Institutions (NPI) within the local government area are controlled and generally financed by local governments. Authority of these institutions is much less than the central or state government, and sometimes they are able to exercise tax imposing power within the local government area.

Expenditure can be defined as the value of payment by the buyers to the sellers in exchange for goods or services. This definition is also common to the institutional unit including government when it comes to government expenditure.

Although government expenditure is one part of government accounts, it is logical that this discussion starts by introducing government accounts. Under the national account framework, government accounts fall under institutional sector accounts. Therefore, the government accounts also consist of a sequence of accounts which have already been described under national accounts. As that the current account, accumulation account and balance sheet are the major components which cover every aspect of government activities.

There is no clear cut clarification for government expenditure accounts in SNA 1993. However, it illustrates different ways to calculate different components of expenditure. Throughout the history of SNAs one of the experiences of government accountants was the difficulty applying principles of classification utilized for other sectors to the government sector (Levin, 1996). Nonetheless, the following sections of this chapter will summarize the provisions of SNA 1993 to formation the government expenditure.

\subsubsection{Government final expenditure}

According to SNA 1993, Government Final Expenditure (GFE) is the aggregate of two main components:

1. Final consumption expenditure, and

2. Gross capital formation of government. 
The following table illustrates the formation of government final expenditure.

Table 1.2- Formation of government final expenditure

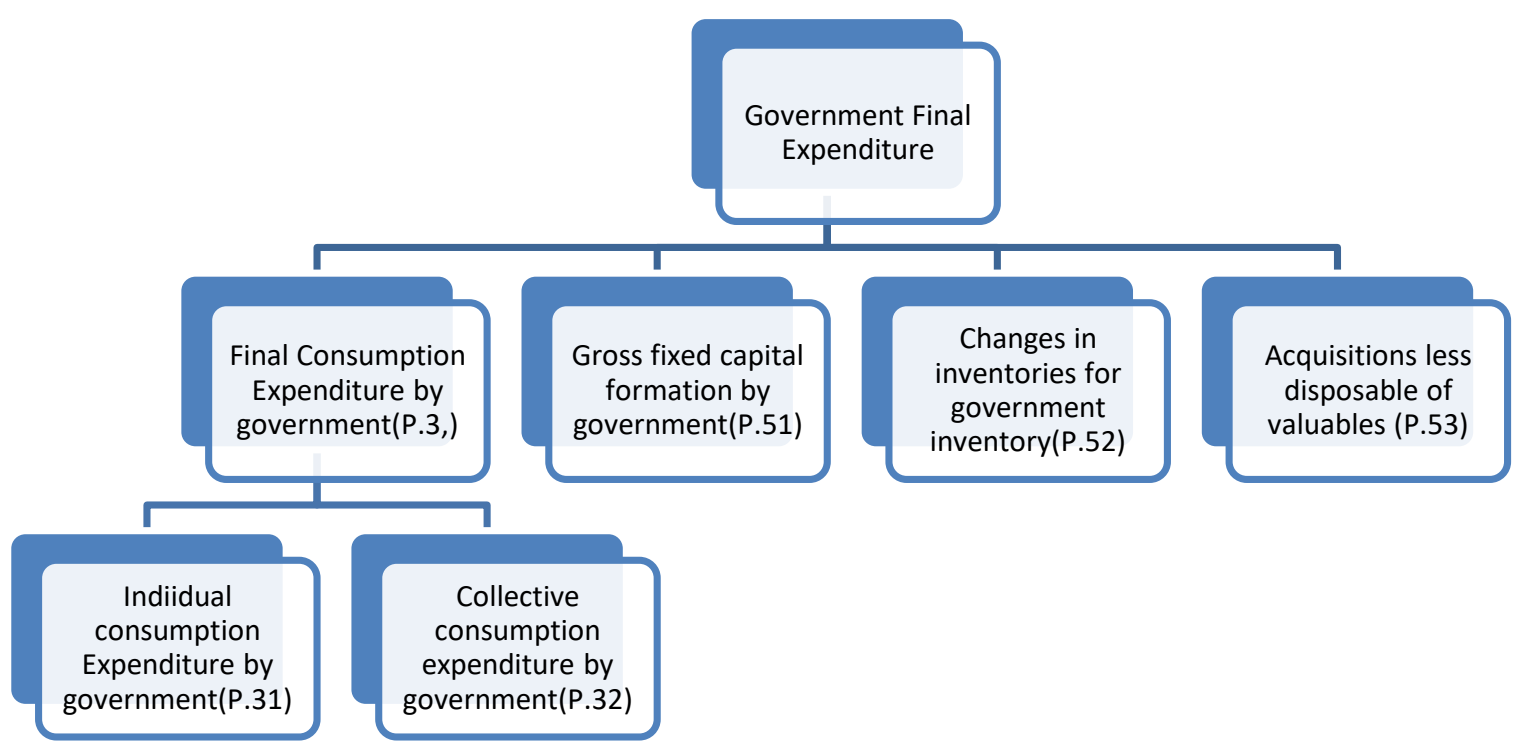

Source: compile by the author according to the SNA 1993

\section{i. Government Consumption Expenditure}

Government's consumption expenditure can be classified in numerous ways. SNA 1993 listed the following as classifications of government consumption expenditure.

a. According to whether the goods or services have been produced by market or non-market producers.

b. According to whether the expenditure is on collective services or individual goods or services;

c.By classification of the functions of government (COFOG);

(International Monetary Fund, 1993)

\section{a. Expenditure on output or market and non-market produces}

This classification is important because most of the final consumption expenditure of the government is expenditure on the output of non-market produces which is free of charge or at a price that is not economically significant to households or the community. Further, this is relates to 
situations where goods are produced by market producers and the distribution cost is borne by the government to distribute those goods to households as social transfers. Those kinds of expenditure are also recorded under social benefits and social assistance.

\section{b. Expenditure on individual and collective goods}

Final Consumption Expenditure is categorized as either individual consumption expenditure (P.31) or collective consumption expenditure (P.32). Both of these categories are introduced by the SNA 1993. Individual consumption expenditure is essentially for "private" consumption, not "public". To identify whether expenditure is for individual or public consumption, SNA 1993 illustrates some characteristics of individual consumption. First, it should be possible to observe and record the acquisition of goods by individual household accounts. Second, an individual or household should have agreed to the provision of the goods and services and take any action necessary to make it possible. Third, acquisition must be done by one household or small group of persons.

Jackson (2000) further illustrates the concept through examples stating that if the government spends money on providing free school education it will benefit individuals and households and can therefore be classified as individual consumption expenditure. Similarly, if government spending is on street lights, the fact that it benefits the community means it can be classified as collective consumption expenditure.

\section{c. Functional Classification}

This classification is based on the "purpose" or "objectives" of the activities. There are a number of benefits to these functional classifications; firstly, they can be used to distinguish between collective services and individual services of the government. Secondly, they provide statistics which can be used for research purposes. For instance, classification of individual consumption by category shows household expenditure on aspects including food, health and education. Thirdly, for the purposes of studying economic growth, these classifications provide a good insight into a company's human capital and investment on research and development.

\section{Classification of total outlays of government functions}

1. General public services

2. Defence affairs and services

3. Public order and safety affairs

4. Education affairs and services 
5. Health affairs and services

6. Social security and welfare affairs and services

7. Housing and community amenity affairs and services

8. Recreational, cultural and religious affairs services

9. Fuel and energy affairs and services

10. Agriculture, forestry, fishing and hunting affairs and services

11. Mining and mineral resource affairs and services, other than fuel manufacturing affairs and services; and construction affairs and services

12. Transportation and communication affairs and services

13. Other economic affairs and services

14. Expenditures not classified by major group

Source: (International Monetary Fund, 1993)

ii. Gross Capital Formation (GCF) is the opposite of consumption expenditure. Though the consumption of goods and services are used in current accounting periods and play no further role in the process of production neither in that accounting period nor in any future accounting period, GCF plays a role in the process of production in future accounting periods (Jackson, 2000). Further, GCF consists of three different categories which are described in the SNA 1993. Those are gross fixed capital formation (P.51), changes in inventories (P.52) and acquisition less disposals of valuables (P.53).

\section{a. Gross Fixed Capital Formation}

According to the SNA 1993, Gross Fixed Capital Formation is ".... Tangible or intangible assets that have come into existence as outputs from processes of production and that are themselves used repeatedly or continuously in other processes of production over periods of time of more than one year..."

b. Changes in inventories are measured by the value of the assets which enter the inventory by means of purchase or acquisition by the owner, and the value of the assets leaving the inventories by selling or other use. 
c. Valuables are not used for production or primary consumption purposes. They are assets which do not depreciate over time under normal conditions, and where there is possibly an increase in value, for example in relation to precious stones, paintings or sculptures.

Having been developed and refined over a period of three centuries, the SNA is now an important and integral part of any government. Despite the importance of the international integrated system of accounts, and the fact that it has been in effect for such a lengthy period of time, many countries, especially developing countries, have not yet attained the standards of the SNA.

\section{References}

CARSON, C. S. 1996. Design of Economic Accounts and the 1993 System of National Accounts. In: KENDRICK, J. W. (ed.) The New System of National Account. Kluwer Academic Publisher.

CLARK, C. 1965. National Income and Outlay. Second Edition ed. Frank Cass \& Co Ltd,London.

INTERNATIONAL MONETARY FUND 1993. System of National Accounts 1993. USA: 'IMF eLibrary'.

JACKSON, D. 2000. The New National Account, USA, Edward Elger Publishing.

JORGENSON, D. \& LANDEFELD, S. 2006. Blueprint for Expanded and Integrated U.S.Accounts:Review,Assesment, and NextSteps. In: JORGENSON, D. \& LANDEFELD, S. (eds.) A New Architecture for the U.S. National Accounts. National Bureau of Economic Research, The University of Chicago Press.

KENADRICK, J. W. 1996. The New System of National Accounts: Introduction and Overview,. In: KENADRICK, J. W. (ed.) ThEe New System of National Accounts. Kluwer Academic Publisher.

LEVIN, J. 1996. Government in the 1993 System of National Accounts. In: KENDRICK, J. W. (ed.) The New System of National Accounts. USA: Kluwer Academic Publishers.

OECD 2012. OECD Factbook 2011-2012. OECD Publishing.

OECD 2013. The 2008 SNA - changes from the 1993 SNA. OECD Publishing.

OHLSSON, I. 1961. On National Accounting, Stockholm, National Institte of Economics Research.

STONE, R. \& MEADE, J. 1977. National Income and Expenditure. Bowes \& Bowes.

TILY, G. 2009. John Maynard Keynes and the Development of National Accounts in Britain, 1895-1941. Review of Income and Wealth, 55, 331-359.

UNITED NATIONS 1968. System of National Accounts. United Nations.

VANOLI, A. 2005. A History of National Accounting, IOS Press. 
